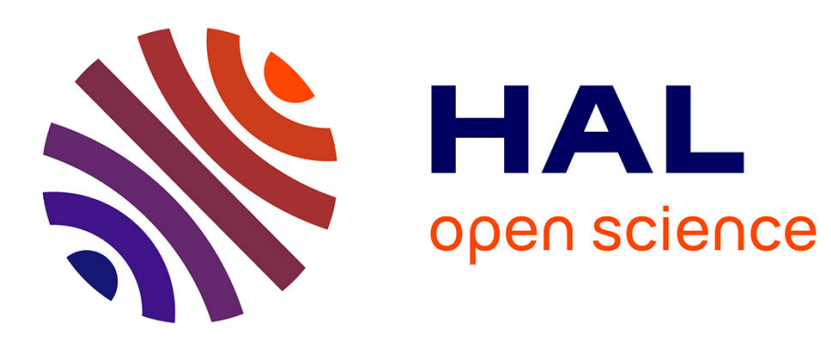

\title{
Effects of loan loss provisions on growth in bank lending: some international comparisons
}

Vincent Bouvatier, Laetitia Lepetit

\section{To cite this version:}

Vincent Bouvatier, Laetitia Lepetit. Effects of loan loss provisions on growth in bank lending: some international comparisons. International Economics, 2012, 132, pp.91-116. hal-01098963

\section{HAL Id: hal-01098963 \\ https://hal.science/hal-01098963}

Submitted on 30 Dec 2014

HAL is a multi-disciplinary open access archive for the deposit and dissemination of scientific research documents, whether they are published or not. The documents may come from teaching and research institutions in France or abroad, or from public or private research centers.
L'archive ouverte pluridisciplinaire HAL, est destinée au dépôt et à la diffusion de documents scientifiques de niveau recherche, publiés ou non, émanant des établissements d'enseignement et de recherche français ou étrangers, des laboratoires publics ou privés. 


\title{
Effects of loan loss provisions on growth in bank
}

\section{lending : some international comparisons}

\author{
Vincent Bouvatier* Laetitia Lepetit ${ }^{\dagger}$
}

January 2012

\begin{abstract}
A dynamic provisioning system is one of the instruments that regulators could use for introducing counter-cyclicality into prudential regulation. The potential effectiveness of such instrument depends on how far actual provisioning practices exacerbate growth in bank lending. We therefore investigate the effects of loan loss provisions on growth in bank lending, making a difference between non discretionary and discretionary loan loss provisions. International comparisons are made between five geographical areas : Europe, Japan, the United-States, Central \& South American and South \& East Asia. Except for Japanese banks, we find a negative and significant effect of non discretionary loan loss provisions on growth in bank lending. This common feature lead us to conclude that banking regulators could reach a consensus concerning the beneficial aspects of a dynamic provisioning system.
\end{abstract}

JEL classification: G21

Keywords: bank lending, loan loss provisions, procyclicality

\footnotetext{
${ }^{*}$ Université de Paris Ouest - Nanterre La Défense, EconomiX - CNRS, Bâtiments G, 200 Avenue de la République, 92001 Nanterre Cedex, France. E-mail: vbouvatier@u-paris10.fr

${ }^{\dagger}$ Université de Limoges, LAPE, 5 rue Félix Eboué, 87031 Limoges Cedex, France. Tel: +33-555-14-92-13, e-mail: laetitia.lepetit@unilim.fr
} 


\section{Introduction}

The financial crisis that started in 2007 puts forward the need for introducing countercyclicality into prudential regulation as one of the most destabilizing elements of the crisis has been the procyclical amplification of financial shocks throughout the banking system, financial markets and the broader economy. Several recommendations have been proposed by the Basel Committee on Banking Supervision (2011) under Basel III to reduce the role of the procyclical factors. Some of these measures concern the adjustment of the regulatory capital requirement with the aim to dampen its cyclicality. The Committee is looking to focus on long-term calibration of the probability of default in the modeling of risk, to introduce a downturn loss-given default and to use an appropriate calibration of the risk functions with parameters that can better reflect "through the cycle" effects. The Committee is further proposing to adjust the capital buffer range, established through the capital conservation mechanism, to ensure that banking sector capital requirements take account of the macrofinancial environment in which banks operate. Bank regulators can slowly increase their capital requirements when excess aggregate credit growth is judged to be associated with a build-up of system-wide risk, signaling those requirements clearly one year in advance. These higher capital requirements will ensure that the banking system has a buffer of capital to protect it against future potential losses. The Basel Committee is also promoting forward-looking provisioning ${ }^{1}$ by strongly supporting the IABS principles to base it on the "expected" (rather than the current "incurred") losses of banks' existing portfolios. This requires changing the accounting standard towards an expected loss approach. The Committee issued for that a set of high level guiding principles that should govern the reforms to the replacement of IAS $39^{2}$.

\footnotetext{
${ }^{1}$ In a dynamic provisioning system, a new element, called the statistical provisions, is introduced. These statistical provisions are defined by accounting rules to cover expected losses. Banks have to evaluate the latent risk over a whole business cycle of their loan portfolio. Statistical provisions are defined as the difference between the estimation of latent losses and specific provisions. During an upswing phase, specific provisions are generally low and banks can therefore build up a fund of statistical provisions. Conversely, during a downturn, specific provisions increase and can be greater than latent losses, which means that the fund of statistical provisions previously accumulated is used to cope with numerous contemporaneous problem loans. As a result, statistical provisions offset the counter-cyclical evolutions of specific provisions, and total loan loss provisions are smoothed over time. See Saurina (2009) for more details.

${ }^{2}$ See Guiding principles for the revision of accounting standards for financial instruments issued by the Basel Committee, August 2009.
} 
According to the limitations of each instrument and/or the complexity of the procyclicality in banking activities, the regulatory framework should be based on the complementarity of instruments and should combine the proposals of the Basel Committee to address procyclicality. However, all countries (except Spain) that already planned to implement Basel III mainly focus on the capital measures, but do not consider replacing the backward looking provisioning system with the suggested forward-looking provisioning system. The main issue in this context is to determine if provisioning practices have pro-cyclical effects and how far banks underestimate risks during cyclical upturns.

This paper contributes to this debate by investigating if existing backward-looking provisioning practices exacerbate growth in lending. Indeed, this point is essential to assess if a dynamic provisioning system would be appropriate for smoothing growth in bank lending. However, provisioning practices and their eventual effects on growth in lending may differ noticeably in different banking systems. This could make it difficult to reach an international consensus between banking regulators concerning the adoption of a dynamic provisioning system. Our aim is therefore to empirically determine if there are country differences in the way provisioning practices affect growth in bank lending. More precisely, we consider three samples of developed countries: Europe, the United States, Japan; and two samples of emerging countries: Central \& South America and South \& East Asia.

While this issue is potentially important for banking regulators, the existing theoretical and empirical literatures are not very well developed. Bouvatier and Lepetit (2012) and Bouvatier and Lepetit (2011) use a partial equilibrium model to show that a backwardlooking provisioning system amplifies the procyclicality of loan markets whereas such an effect disappears when statistical provisions are used to smooth the evolution of total loan loss provisions. Working on a panel of European commercial banks for the period 1992-2004, Bouvatier and Lepetit (2008) find that loan loss provisions (LLP) made in order to cover expected future loan losses (non-discretionary LLP) amplify growth in lending. By contrast, loan loss provisions used for management objectives (discretionary LLP) do not have a significant effect. We extend this work by making international comparisons on the effects of loan loss provisioning practices on growth in lending. We consider commercial banks, but also cooperative \& mutual banks and savings banks for three samples of developed countries 
(Europe, Japan and the United States) and two samples of emerging countries (Central \& South America and South \& East Asia).

Our results show that non-discretionary loan loss provisions under a backward-looking provisioning system impact significantly on growth in lending in all the countries we consider, except for Japan. In addition, this effect is stronger in emerging countries and in Europe than in the United States (U.S.). As we show that a backward-looking provisioning system amplifies the procyclicality of bank lending in a large set on countries, our results support the proposal of the Basel Committee to implement a forward-looking provisioning system at the international level in addition to the capital measures already adopted to address procyclicality.

The remainder of the paper is organized as follows. Section 2 presents data and descriptive statistics. Section 3 presents the estimates on the determination of loan loss provisions. Section 4 discusses the effects of loan loss provisions on growth in bank lending. Section 5 concludes the paper.

\section{Datasets and descriptive statistics}

We consider five different geographical areas: Europe, Japan, the United States, Central \& South America and South \& East Asia. We use (unconsolidated) financial statement data extracted from Bankscope. We use information on commercial, cooperative \& mutual and savings banks. Table A1 in the appendix gives a breakdown of banks by country and bank type.

Our European dataset covers the period 1995-2008 and includes commercial, cooperative \& mutual and savings banks for the following countries ${ }^{3}$ : Denmark, France, Italy, Norway, Spain $^{4}$, Sweden, Switzerland, and United Kingdom. Bankscope provides information on income statements and balance sheets for 3040 commercial, cooperative \& mutual and savings

\footnotetext{
${ }^{3}$ We extracted data from 17 European countries (the European Union at 15, plus Norway and Switzerland), but for some countries a majority of banks does not provide information on some variables needed by this study (especially non performing loans and total capital ratio). So finally, we only end up with 8 European countries and have to drop Austria, Belgium, Finland, Germany, Greece, Ireland, Luxembourg, Netherlands and Portugal. We also do not include in our sample Eastern and Central Europe as Bankscope provides information on some variables we need (such as non-performing loans) for only few banks.

${ }^{4}$ As Spain implemented a dynamic provisioning system in 2000, we only keep in our sample data on spanish banks for the period 1995-1999.
} 
banks for these 8 countries. Not all these banks do provide information on the variables needed for this study, especially non-performing loans and total capital ratio. After data cleaning, we end up with an unbalanced panel of 1636 banks. The weight of Italian banks is preponderant in our European dataset due to the important number of cooperative banks in Italy and to the good reporting of these banks in Bankscope. This point will be carefully considered during the estimations, running subsample estimations without Italian banks.

We identify 10296 U.S. commercial and savings banks for which income statements and balance sheets are provided for the period 1995-2008 ${ }^{5}$. Information availability on our variables of interest and data cleaning leave us with an unbalanced panel of 9421 U.S. banks.

The Central \& South America dataset covers the period 1995-2008 for the following countries : Argentina, Bolivia, Brazil, Chile, Colombia, Costa Rica, Ecuador, Mexico, Paraguay, Peru, Uruguay and Venezuela. Data availability for other Central \& South America countries is limited (considering variables needed for this study). Bankscope provides information on 895 banks from these 12 countries. Information availability on our variables of interest and data cleaning leave us with an unbalanced panel of 632 banks. These banks are mainly commercial banks. We are not able to include the total capital ratio in our estimates for this dataset because only $25 \%$ of banks provide this information.

Bankscope provides information on 968 Japanese commercial and cooperative \& mutual banks $^{6}$, but only 166 over these 968 banks have financial statement information available for the period 1995-1997. We therefore decided to restrict our analysis to a shorter period for Japanese banks, from 1998 to 2008. Information availability and data cleaning leave us with an unbalanced panel of 689 Japanese banks. As for Central \& South American banks, we also dropped the total capital ratio from our estimations in this sample because this variable is provided only for $35 \%$ of our dataset.

Finally, as for Japan, data availability in Bankscope for South \& East Asian banks over the period 1995-1997 is very weak. Our dataset for the South \& East Asian banks covers therefore the period 1998-2008 for the following countries : Indonesia, South Korea, Malaysia,

\footnotetext{
${ }^{5}$ Cooperative \& mutual american banks are not included in our analysis as financial information is only available for 6 banks.

${ }^{6}$ Japanese savings banks are not included in our analysis as financial information is only available for one of them.
} 
Philippines, Taiwan and Thailand ${ }^{7}$. Bankscope provides information for 395 banks in these 6 countries. Information availability and data cleaning leave us with an unbalanced panel of 245 banks.

Table 1 presents some general descriptive statistics for our different datasets. Loans are the main bank assets and deposits are the main resources in our five datasets. The ratio of loans to total asset is between $51.96 \%$ for Central \& South American banks and $66.79 \%$ for European banks (without Italy). Considering deposits to total assets, this ratio is between $64.41 \%$ for Italian banks and $92.16 \%$ for Japanese banks. Mean tests ${ }^{8}$ highlight significant differences in the quality of loan portfolios. U.S. banks present the lowest ratio of non-performing loans to total assets while Japanese banks display the highest ratio. Note that U.S. banks have a relatively high ratio of loan loss provisions compared to their ratio of non-performing loans while Japanese banks make relatively few loan loss provisions. We also find significant differences in terms of profitability. Japanese banks are on average the last profitable with negative return on assets and return on equity, whereas U.S. banks and Central \& South American banks are more profitable than European or South \& East Asian banks. Mean tests further show that growth rates in bank lending and deposits are particularly weak for Japanese banks. The growth rate in bank lending is $2.29 \%$ for Japanese banks while it is around $10 \%$ for other datasets.

\section{[Insert Table 1]}

\section{Decomposition of loan loss provisions}

The literature on provisioning practices shows that loan loss provisions are made up of two components. The non-discretionary component represents loan loss provisions made to cover expected credit losses (Whalen, 1994; Beaver and Engel, 1996, Hasan and Wall, 2004). With backward-looking practices, this component is mainly related to the identification of problem loans (i.e. non-performing loans) and exhibits a cyclical pattern (Laeven and Majnoni, 2003; Bikker and Metzemakers, 2005). The discretionary component captures loan loss provisions

\footnotetext{
${ }^{7}$ Bankscope does not provide enough information on the others South \& East Asian countries (considering variables needed by this study) to include them in our analysis.

${ }^{8}$ These tests are available upon request.
} 
made for managerial objectives such as income smoothing, capital management or signalling (Ahmed et al., 1999; Hasan and Wall, 2004; Kanagaretnam et al., 2004; Anandarajan et al., 2007; Fonseca and Gonzalez, 2008; Kanagaretnam et al., 2009). We need to differentiate these two components to accurately analyze if non-discretionary LLP have an effect on growth in lending.

\subsection{The empirical specification}

We use an empirical specification based on Ahmed et al. (1999) and Bouvatier and Lepetit (2008) to decompose loan loss provisions into non-discretionary and discretionary LLP.

In a backward-looking provisioning system, non-discretionary LLP are mainly related to non-performing loans. We use the ratio of non-performing loans to total assets at the end of the year $t\left(N P L_{i, t}\right)$ and the first difference of $N P L_{i, t}\left(\triangle N P L_{i, t}=N P L_{i, t}-N P L_{i, t-1}\right)$ as explanatory variables. These two variables are good indicators of the expected loss identified by banks for their loan portfolio. They should display a positive relationship with loan loss provisions. We also include the risk of default for the overall credit portfolio, measured by the ratio of net loans to total assets $\left(L_{i, t}\right)$. The coefficient associated with this variable should be positive. Finally, we consider the annual growth rate of GDP $\left(\dot{y}_{i, t}\right)$, which should affect loan loss provisions negatively. Indeed, the creditworthiness of banks' customers depends on the economic condition.

The discretionary component comprises loan loss provisions made to fulfill managerial objectives. First, banks can use loan loss provisions for income smoothing, i.e. banks can understate (overstate) loan loss provisions when earnings are expected to be low (high). We consider the ratio of earnings before taxes and loan loss provisions to total assets $\left(E R_{i, t}\right)$ to test if banks use loan loss provisions to smooth their income. A positive relationship between the variable $E R_{i, t}$ and LLP will be consistent with the income smoothing hypothesis. Second, banks can use loan loss provisions for capital management. Banks with low regulatory capital could be more inclined to make loan loss provisions because general LLP are included (to a certain extent) in Tier 2 capital and are tax deductible in most countries ${ }^{9}$. We use the total

\footnotetext{
${ }^{9}$ The Basel I accord allows general loan loss reserves (which include general loan loss provisions) to count
} 
capital ratio $\left(T C R_{i, t}\right)$ to capture this behavior for European, U.S. and South \& East Asian banks $^{10}$. We expect a negative relationship with loan loss provisions. However this negative relationship could also result from the risk profiles of banks (Bikker \& Metzemakers, 2005). Riskier banks might record more losses, more loan loss provisions and hold less regulatory capital. As Bankscope provide limited information on the total capital ratio for Japanese and Central \& South American banks, we alternatively use the ratio of equity to total assets $\left(E_{i, t}\right)$ to capture the capital management behavior. Third, banks can also use loan loss provisions to signal their financial strength. The one-year-ahead change of earnings before taxes and loan loss provisions $\left(S I G N_{i, t}=E R_{i, t+1}-E R_{i, t}\right)$ is generally used in the literature to capture such behavior. A positive relationship with loan loss provisions would indicate that banks might signal a future improvement of earnings to their clients and investors by increasing their loan loss provisions.

The empirical specification for loan loss provisions is therefore given by :

$$
\begin{aligned}
L L P_{i, t}= & \alpha_{0}+\alpha_{1} L L P_{i, t-1}+\alpha_{2} N P L_{i, t}+\alpha_{3} \Delta N P L_{i, t}+\alpha_{4} L_{i, t}+\alpha_{5} \dot{y}_{i, t} \\
& +\alpha_{6} E R_{i, t}+\alpha_{7} T C R_{i, t}+\alpha_{8} S I G N_{i, t}+\varepsilon_{i, t}
\end{aligned}
$$

where $L L P_{i, t}$ is the ratio of loan loss provisions (specific provisions plus general provisions) to total assets at the end of the year $t$ for bank $i$.

We consider a dynamic adjustment of loan loss provisions. If banks adjust their provisions slowly to recognize potential losses against loans or if default events are concentrated in time, then provisions could exhibit time dependency. Dummy variables are included to control for bank type (commercial, cooperative \& mutual or savings banks). In addition, we include country and time dummies for our European, Central \& South American and South \& East Asian datasets. We do not include time dummies for U.S. and Japanese banks since a macro variable $\left(\dot{y}_{i, t}\right)$ is considered in the specification.

Equation (1) is estimated to compute the non-discretionary component and the discre-

toward Tier 2 capital up to a maximum of $1.25 \%$ of risk-weighted assets. For banks using the IRB approach, Basel II changes this limit to $0.6 \%$ of credit-risk-weighted assets.

${ }^{10}$ The capital management behavior will be more accurately captured using Tier1 capital ratio but a majority of banks do not give specific information on their level of Tier 1 and Tier 2 . 
tionary component of LLP. We assume that these two components are linear functions of the variables included in equation (1).

\subsection{The estimation methodology}

We use the Blundell and Bond (1998) dynamic panel estimator to estimate equation (1). This estimator is known as the "system GMM" estimator. It combines two equations, the original equation and a transformed one. The transformed equation can be the first difference of the original equation. In this paper, we use the forward orthogonal deviations transformation of the original equation as suggested by Arellano and Bover (1995). In addition, we report the two-step estimator including the Windmeijer (2005) finite-sample correction. Finally, to limit the number of instruments, we restrict at 4 the lag range used in generating the instruments and we use the "collapse option" (Roodman, 2006) ${ }^{11}$. The "GMM-style" instruments are applied only on the lagged dependent variable $\left(L L P_{i, t-1}\right)$. The other variables are considered as strictly exogenous.

The validity of estimates is checked with the $\operatorname{AR}(2)$ test and the Hansen test. The $\operatorname{AR}(2)$ test corresponds to the Arellano-Bond test which tests for autocorrelation aside from the fixed effects. The presence of such autocorrelation makes lag 2 invalid as instrument. The Hansen test allows to check the validity of the whole set of instruments. We also ensure that there is no multicollinearity problem computing the variance inflation factors (VIF) and the correlation matrix.

Table 2 and 3 presents the results obtained for equation (1). We test the robustness of our results by considering three alternative specifications. In specification (1.a), we only consider the variables related to the non-discretionary component of loan loss provisions. In specifications (1.b) and (1.c), the discretionary and non-discretionary components are jointly considered, taking either the total capital ratio (specification (1.b)) or the equity to total assets ratio (specification (1.c)) to capture the capital management behavior ${ }^{12}$. Comparison between specification (1.a) and (1.b) or (1.c) allows checking that the results are

\footnotetext{
${ }^{11}$ With the standard approach, the instrument count depends both on the time period count and the lag available count. With the "collapse" approach, it depends only on the lag available count.

${ }^{12}$ Running equation (1) with $E_{i, t}$ instead of $T C R_{i, t}$ allows to considerably increase the number of observations for Europe. In addition, specification (1.b) is not performed for Japanese and Central \& South American banks because $T C R_{i, t}$ is only available for a few number of banks in these two datasets.
} 
stable whether or not we introduce the discretionary component. The proxy used to test the hypothesis that banks might used loan loss provisions to signal their financial strength $\left(S I G N_{i, t}\right)$ is never significant but reduces the sample size as we use one-year-ahead changes of earnings before taxes and loan loss provisions. Estimates with this variable are therefore not reported ${ }^{13}$.

Table 2 presents the results obtained for European and Japanese banks. Estimates for European banks are run firstly on the whole sample and secondly on the subsample excluding Italian banks. ${ }^{14}$ This subsample estimate allows checking if results are driven by the large number of Italian banks in the European dataset. Table 3 presents the results obtained for U.S., Central \& South America and South \& East Asian banks.

\subsection{Results}

Tables 2 and 3 show that provisioning practices have common features across our different datasets. The ratio of non-performing loans $\left(N P L_{i, t}\right)$ and the GDP growth rate $\left(\dot{y}_{i, t}\right)$ affect significantly loan loss provisions in all estimations and the first difference of the ratio of nonperforming loans $\left(\triangle N P L_{i, t}\right)$ is not significant only for South \& East Asian banks. These results support the hypothesis that backward-looking practices lead to a cyclical pattern of loan loss provisions in all banking systems we consider. The coefficient of the GDP growth rate is between -0.02 for Japanese banks and -0.08 for Central \& South American banks. In addition, the ratio of non-performing loans and its first difference reach their highest magnitudes respectively for U.S. banks with 0.16 and for Central \& South American banks with 0.12 . The smallest magnitudes are obtained for European banks with a coefficient of 0.03 for both $N P L_{i, t}$ and $\triangle N P L_{i, t}$. Concerning the discretionary behavior, our results are consistent with the hypothesis that banks use loan loss provisions to smooth their income in all the different countries we consider. Indeed, the coefficient of the ratio of earnings before taxes and loan loss provisions to total assets $\left(E R_{i, t}\right)$ is significant and positive in all estimates. The smaller coefficient of $E R_{i, t}$ is observed for U.S. banks (0.06) whereas the

\footnotetext{
${ }^{13}$ The estimates including the variable $S I G N_{i, t}$ are available upon request.

${ }^{14}$ We also run estimates for European banks excluding year 2008 from the sample. The Basel II agreement starts to be implemented in Europe in 2008 and we check therefore that our results are not affected by this modification in the regulatory framework. These estimates are not reported to save space but are available upon request.
} 
highest one is obtained for South \& East Asian banks (0.16).

Our results also show that banks from our different datasets behave differently in some respects regarding their provisioning practices. Firstly, the coefficient of the lagged dependent variable is significant for European, U.S. and Central \& South American banks but not for Japanese and South and East Asian banks ${ }^{15}$. This coefficient is around 0.30 for U.S. and Central \& South American banks and around 0.20 for European banks. Banks in these countries therefore adjust loan loss provisions gradually to recognize potential losses against loans. Secondly, the coefficient of the variable net loans to total assets $\left(L_{i, t}\right)$ is not significant for South \& East Asian banks and it is either not significant or has an unexpected negative sign depending on the specification for Japanese banks. As a result, this variable does not seem to correctly capture the risk of default for the overall credit portfolio, or loan loss provisions are not affected by this credit risk measure in these two samples. We note that the variable $L_{i, t}$ is also not significant in specification (1.b) for European banks. However, this could result from a correlation between the variables $L_{i, t}$ and $T C R_{i, t}$ even if the VIF remain weak. Thirdly, the capital management behavior is not a significant determinant of loan loss provisions practices of Central \& South American banks. Moreover, although this behavior is significant for our whole sample of European banks, subsample estimates in Table 2 show that this result is driven by the behavior of Italian banks. Coefficients of the variables $T C R_{i, t}$ and $E_{i, t}$ turn out to be not significant at the $10 \%$ level when Italian banks are excluded from our European dataset. Lastly, the provisioning behavior of South \& East Asian banks is less accurately captured than for the other datasets. Indeed, the lagged dependent variable and net loans to total assets do not significantly affect loan loss provisions. We also note that the first difference of the ratio of non-performing loans $\left(\triangle N P L_{i, t}\right)$ is not significant and that the validity of instruments $(\operatorname{AR}(2)$ and Hansen tests) is not rejected only at the $5 \%$ or $1 \%$ level. These discordant results could be explained by the limited sample available for South \& East Asian banks or by important heterogeneities between provisioning practices between South East Asian countries.

\footnotetext{
${ }^{15}$ We test the robustness of our results by running Equation (1) without the lagged dependent variable for Japanese and South \& East Asiab banks. Results obtained in Table 3 are not modified. Similar results are also obtained with the fixed or random effects estimators. These results are available upon request.
} 


\section{[Insert Tables 2 and 3]}

\subsection{Computation of the non-discretionary and the discretionary components of LLP}

We use the estimates of equation (1) to compute the non-discretionary and discretionary components of LLP. It is assumed that these two components are linear functions of the different variables included in equation (1). Thus, they are computed as the sum of the products of their explanatory variables times the corresponding estimated coefficients from equation (1). More precisely, we use the specification (1.c) which includes both non-discretionary and discretionary provisioning behavior ${ }^{16}$. We compute several measures of the non-discretionary components to test the robustness of our results.

First, the non-discretionary component of LLP is defined by:

$$
N D I S C 1_{i, t}=\alpha_{1} L L P_{i, t-1}+\alpha_{2} N P L_{i, t}+\alpha_{3} \Delta N P L_{i, t}+\alpha_{4} L_{i, t}+\alpha_{5} \dot{y}_{i, t}
$$

when all the coefficients $\alpha_{i}$ are significant. If a coefficient is not significant or has the opposite expected sign in equation (1.c), the variable associated with this coefficient is dropped ${ }^{17}$.

Second, we compute a non-discretionary LLP component that excludes the GDP growth rate $\left(\dot{y}_{i, t}\right)$ and includes only bank level variables:

$$
N D I S C 2_{i, t}=\alpha_{1} L L P_{i, t-1}+\alpha_{2} N P L_{i, t}+\alpha_{3} \Delta N P L_{i, t}+\alpha_{4} L_{i, t} .
$$

This specification allows checking if the possible effect of non-discretionary loan loss provisions on growth in lending does not result from the presence of the GDP growth rate in its definition.

Third, we compute a non-discretionary LLP that also includes the income smoothing behavior :

$$
N D I S C 3_{i, t}=\alpha_{1} L L P_{i, t-1}+\alpha_{2} N P L_{i, t}+\alpha_{3} \Delta N P L_{i, t}+\alpha_{4} L_{i, t}+\alpha_{5} \dot{y}_{i, t}+\alpha_{6} E R_{i, t} .
$$

\footnotetext{
${ }^{16}$ The specification (1.b) also considers the non discretionary and the discretionary components of LLP; but the capital management hypothesis is tested using the total capital ratio $\left(T C R_{i, t}\right)$ which is only available for a few number of banks compared to the ratio of equity to total assets $\left(E_{i, t}\right)$ used in specification (1.c).

${ }^{17}$ For example, for Japanese banks, we have : $N D I S C 1_{i, t}=\alpha_{2} N P L_{i, t}+\alpha_{3} \Delta N P L_{i, t}+\alpha_{5} \dot{y}_{i, t}$ since the variable $L L P_{i, t-1}$ does not have a significant effect and $L_{i, t}$ has an unexpected negative and significant sign.
} 
The income smoothing behavior could mitigate the cyclical pattern of non-discretionary LLP and thus their potential effect on growth in lending. Indeed, under the income-smoothing behavior, banks choose accruals to minimize the variance of reported earnings. This implies that loan loss provisions increase during an expansionary phase and decrease during a recessionary phase. We can therefore test if such a behavior may offset the evolution of non-discretionary provisions by using $N D I S C 3_{i, t}$ instead of $N D I S C 1_{i, t}$ or $N D I S C 2_{i, t}$.

Finally, we compute a measure of the discretionary component of LLP defined as:

$$
D I S C_{i, t}=L L P_{i, t}-N D I S C 1_{i, t} .
$$

We assume with such a specification that the discretionary component is fully the part of loan loss provisions which is not identified as non-discretionary. The advantages of this

definition are twofold. It can be applied for each dataset, regardless of the significance of variables capturing the discretionary behavior. It also allows to test if loan loss provisions that are not identified as discretionary also matter for growth in lending.

These discretionary and non discretionary variables are used to test the impact of provisioning behaviors on bank lending.

\section{Provisioning practices and growth in lending}

\subsection{Specification of growth in lending}

We use a similar approach to Bouvatier and Lepetit (2008) to investigate the effect of the non-discretionary and discretionary components of loan loss provisions on growth in lending. We estimate several specifications since we retained three different definitions to compute the non-discretionary component of loan loss provisions. We start with the following specification:

$$
\dot{L}_{i, t}=\beta_{0}+\beta_{1} N D I S C 1_{i, t}+\beta_{2} \dot{D}_{i, t}+\beta_{3} E_{i, t-1}+\beta_{4} T A_{i, t-1}+u_{i, t},
$$

where $\dot{L}_{i, t}$ is the growth rate of net loans. We expect that the non-discretionary component $\left(N D I S C 1_{i, t}\right)$ affects growth in lending negatively if the hypothesis that existing backwardlooking provisioning systems exacerbate bank's procyclicality behavior is consistent. An 
increasing cost of lending represented by a rise of non-discretionary loan loss provisions should reduce a bank's incentive to expand its loans. We control for the growth rate of deposits $\left(\dot{D}_{i, t}\right)$, the equity ratio $\left(E_{i, t-1}\right)^{18}$ and the size measured by the logarithm of total assets $\left(T A_{i, t-1}\right)$. Dummy variables are also included in the specification to control for bank type (commercial, cooperative \& mutual or savings banks), time effect and country effect. Time and country dummies allow us to control for changing macroeconomic conditions.

The effect of non-discretionary loan loss provisions on growth in lending is also estimated alternatively with variables $N D I S C 2_{i, t}$ and $N D I S C 3_{i, t}$ instead of $N D I S C 1_{i, t}$. We expect that considering $N D I S C 2_{i, t}$ instead of $N D I S C 1_{i, t}$ should not modify the results of the estimation. Our results should be robust to whether or not the GDP growth rate is included in the non-discretionary component. In addition, considering $N D I S C 3_{i, t}$ instead of $N D I S C 1_{i, t}$ could modify the results. If $N D I S C 3_{i, t}$ turns out to be not significant while $N D I S C 1_{i, t}$ is significant, this would indicate that income smoothing behavior would mitigate the effect of non-discretionary loan loss provisions on growth in lending.

We consider a last specification in which we include jointly the variables $N D I S C 1_{i, t}$ and $D I S C_{i, t}$. We expect that controlling for the discretionary component should not modify the effect of non-discretionary loan loss provisions on credit variations. Moreover, we do not have any a priori about the effect of $D I S C_{i, t}$ on growth in lending.

Equation (6) is estimated with the "system GMM" estimator. As the non-discretionary $\left(N D I S C 1_{i, t}, N D I S C 2_{i, t}\right.$ or $\left.N D I S C 3_{i, t}\right)$ and the discretionary components $\left(D I S C_{i, t}\right)$ of LLP are computed using the coefficients from the estimate of equation (1), they might contain measurement error. These variables are therefore instrumented to deal with this problem. Variable $\dot{D}_{i, t}$ is also instrumented because it could be endogenous. We restrict at 4 the lag range used in generating the instruments and we use the "collapse option" (Roodman, 2006) to limit the number of instruments. Variables $E_{i, t-1}$ and $T A_{i, t-1}$ are included with a lag to avoid simultaneity and endogeneity problems. They are therefore not instrumented with GMM-style instruments.

\subsection{Empirical results}

\footnotetext{
${ }^{18}$ Considering the equity ratio $\left(E_{i, t-1}\right)$ rather than the total capital ratio $\left(T C R_{i, t-1}\right)$ allows to estimate the same specification for each sample.
} 
Tables 4 and 5 display our results for the different datasets. Four specifications are reported for each dataset. Specification (2.a) corresponds to the estimation of equation (6). In specification (2.b), variable $N D I S C 2_{i, t}$ is considered instead of variable $N D I S C 1_{i, t}$ while in specification (2.c), variable $N D I S C 3_{i, t}$ is considered instead of variable $N D I S C 1_{i, t}$. Specification (2.d) includes both the non-discretionary component $N D I S C 1_{i, t}$ and the discretionary component $D I S C_{i, t}$.

The coefficient associated with the growth rate of deposits $\left(\dot{D}_{i, t}\right)$ is positive and significant in the four specifications for all datasets. The magnitude of the coefficient is smallest for South and East Asian banks and highest for U.S. banks. Concerning the two other control variables, the equity ratio $\left(E_{i, t-1}\right)$ and the size $\left(T A_{i, t-1}\right)$, the estimated coefficients are negative but turn frequently non significant.

In specification (2.a), variable $N D I S C 1_{i, t}$ has a negative and significant effect at the $1 \%$ or $5 \%$ level in all datasets except for Japanese banks, where it is not significant. This negative impact of non-discretionary loan loss provisions on growth in lending suggests that backward-looking provisioning practices affect cyclicality in bank lending. Low specific loan loss provisions during upswing phases of the economic cycle encourage banks to expand credit, whereas the sudden identification of problem loans during downturns constrains banks to make loan loss provisions, which reduces their incentive to supply new credits. The sensitivity of growth in lending to non-discretionary loan loss provisions is however different depending on the banking system ${ }^{19}$. The highest coefficient is observed for European banks $(-15.07)$ and the lowest effect (excluding Japanese banks) is obtained for U.S. banks $(-3.83)^{20}$. The estimated coefficient for Central \& South American banks (-3.84) is close to the lowest value while the coefficient for South and East Asian banks (-15.05) is close to the one obtained for European banks. Concerning the sample of European banks without Italy, the coefficient

\footnotetext{
${ }^{19}$ With backward-looking practices, cyclical factors such as the evolution of non performing loans or more generally the economic situation determine loan loss provisions (i.e. have a direct effect on banks' profits) and then affect bank lending. Note that with our approach we do not estimate directly the marginal effect of loan loss provisions on loan growth.

${ }^{20}$ The high value of the coefficient is explained by the difference of scale between loan loan provisions and the growth rate of loans. Descriptive statistics in Table 1 show that the lowest value of the mean of LLP is observed for US banks (0.28\%) and the highest value for Central \& South American banks (1.64\%), whereas the mean of the growth rate of loans ranges from $2.29 \%$ for Japanese banks to $11.71 \%$ for South \& East Asian banks.
} 
$(-13.52)$ is slightly lower than the one obtained for the whole sample of European banks.

Specification (2.b) in tables 4 and 5 shows that we obtain similar results when we use variable $N D I S C 2_{i, t}$ (excluding the GDP growth rate) instead of $N D I S C 1_{i, t}$. It implies that the negative impact of non-discretionary loan loss provisions on growth in lending does not depend on the effect of the GDP growth rate on LLP.

In specification (2.c), the effect of non-discretionary loan loss provisions on growth in lending is captured by the variable $N D I S C 3_{i, t}$ which includes the proxy used to capture the income smoothing behavior. As in specifications (2.a) and (2.b), we find a significant and negative coefficient associated with $N D I S C 3_{i, t}$ for European, U.S., South \& East Asian and Central \& South American banks. This variable is not significant only for Japanese banks, as previously. These results imply that the income smoothing behavior does not mitigate the effect of non-discretionary loan loss provisions on growth in lending. We can, however, note that the coefficients associated with variable $N D I S C 3_{i, t}$ are slightly weaker (in absolute value) than the ones obtained for variable $N D I S C 1_{i, t}$, but the income smoothing behavior is not strong enough to completely offset the evolution of non-discretionary provisions. Our results therefore highlight that the income smoothing behavior is not the appropriate solution to mitigate the cyclical pattern of non-discretionary loan loss provisions and to dampen their effect on growth in lending. The appropriate solution could come from the banking regulator with the implementation of a dynamic provisioning system. In such a system, the current cyclical pattern of loan loss provisions will be mechanically mitigated and consequently their effect on growth in lending will be limited.

We further jointly consider, in specification (2.d), the effect of the non-discretionary component and the total discretionary component $\left(D I S C_{i, t}\right)$ of LLP on growth in lending. The coefficient of the non-discretionary component remains negative and significant as in specifications (2.a), (2.b) and (2.c), while the effect of the discretionary component of LLP is not significant at the $10 \%$ level. Loan loss provisions which are not made to cover expected losses are therefore not relevant to determine growth in lending.

[Insert Tables 4 and 5] 
Overall we find that the non-discretionary component of LLP amplifies the credit cycle for all the developed and emerging countries we consider, except for Japan. It implies that a backward-looking provisioning system leads banks to underestimate expected credit risk and as a consequence reduce non-discretionary LLP during an economic upswing. Conversely, banks have to charge provisions too late during the downturn. Bank profits and subsequently bank capital are directly affected which decrease the bank's incentive to grant new loans and increase the cyclicality of its lending. Our results suggest that such an impact of loan loss provisions on bank lending does not exist in Japan. This can be explained by the specificities of the Japanese banking system. Descriptive statistics in Table 1 show that Japanese banks have the highest non-performing loans ratio but make few loan loss provisions. In addition, they have the lowest ROE, ROA and growth rate of bank lending. With all these characteristics, it makes sense that non-discretionary loan loss provisions have no effect on growth in bank lending.

\subsection{Simulation exercise}

We further simulate a shock on the non-discretionary component of loan loss provisions to appreciate the magnitude of its impact on the growth of bank lending in the different group of countries we consider. We use the estimates of specification (2.a) (see Tables 4 and 5) to graphically represent the effects of two different shocks on the bank lending growth rate (see Figure 1).

Firstly, we consider a shock of the same amplitude for all the countries by considering an increase of 0.3 for the non-discretionary component of LLP $\left(N D I S C 1_{i, t}\right)$. Such an increase corresponds roughly to one standard error of $N D I S C 1_{i, t}$ for the developed countries (Europe, Japan or the U.S.), but not for emerging countries where the standard error of $N D I S C 1_{i, t}$ is higher (1.64 for Central \& South America and 0.54 for South \& East Asia). The response of the bank lending growth rate to this increase in non-discretionary LLP directly depends on the coefficient of $N D I S C 1_{i, t}$ (Tables 4 and 5 ). Figure 1 shows that the response to this shock is stronger for Europe and South \& East Asia, with a magnitude of -4.5\%. The magnitude of the responses is lower and almost identical for the U.S. and Central \& South America $(-1,1 \%)$, but they are significant according to estimates in Table 5. Japan presents 
the lowest decrease in the bank lending growth rate $(-0.5 \%)$ and this can be considered as not significant according to estimates in Table 4.

Secondly, we consider a shock of different amplitude for each group of countries in order to take into account that the range of variation of $N D I S C 1_{i, t}$ is not similar across countries. We simulate for that the impact of an increase in the non-discretionary component corresponding to one standard error of $N D I S C 1_{i, t}$. We can see in Figure 1 that the responses of the growth rate in bank lending to this shock for developed countries are not very different from the ones obtained with the first shock. The amplitude of the first and the second shocks are mainly similar for these countries ${ }^{21}$. The effect remains stronger in Europe than in the U.S. and it is not significant in Japan. Interestingly, the magnitude of this second shock is very different for our two groups of emerging countries. The response of the growth rate in bank lending is $-6,3 \%$ for Central \& South America and $-8,3 \%$ for South \& East Asia. More important swings in non-discretionary loan loss provisions lead therefore to stronger variations in bank lending in emerging countries than in developed countries.

These results highlight that it is important to not only consider the coefficient associated with the non-discretionary component $N D I S C 1_{i, t}$ but also the variation occurring in nondiscretionary loan loss provisions to accurately evaluate the impact of provisioning practices on growth in bank lending. Our results show that backward backward-looking provisioning systems exacerbate banks' lending fluctuations in both developed and emerging countries, but with a stronger impact for emerging countries.

\section{[Insert Figure 1]}

\section{Conclusion}

We examined whether backward-looking provisioning practices amplify growth in bank lending. This is of obvious interest from a public policy point of view, as banking regulation should move toward a dynamic provisioning system if existing backward looking provisioning system increase the procyclicality of bank lending. We conducted a comparative study on three samples of developed countries (Europe, Japan and the United States) and two samples of emerging countries (Central \& South America and South \& East Asia).

\footnotetext{
${ }^{21}$ The standard error of $N D I S C 1_{i, t}$ is respectively 0.24 for Europe, 0.31 for Japan and 0.34 for the U.S.
} 
We find that backward-looking provisioning practices amplify the cyclicality of bank lending, with a stronger impact for emerging countries. Indeed, our results show that the non-discretionary component of LLP has a negative and significant effect on growth in bank lending in all the countries we considered, except for Japan, with a higher amplitude for emerging countries. A backward-looking provisioning system implies that during an economic upswing, banks tend to underestimate expected credit risk and as a consequence reduce non-discretionary LLP. Banks' incentives to grant new loans are therefore reinforced since lending costs are understated. On the other hand, sudden identification of problem loans during an economic downturn constrains banks to make non-discretionary loan loss provisions, which reduces their incentive to supply new credit.

Countries with a backward-looking provisioning system could therefore benefit from the implementation of a dynamic provisioning one. As we find that backward-looking provisioning practices impact on growth in lending for Europe, the United States, Central \& South America and South \& East Asia, it should facilitate the adoption of a dynamic provisioning system at the international level. We showed that the advantages of such a system could be even more relevant for emerging countries and Europe than for the United States.

Regulators should combine capital measures and a forward-looking provisioning system that are designed to complement each other to address procyclicality as suggested by the Basel Committee. The reform of the provisioning system should focus on strengthening the banking system against expected losses, while the capital measures focus on unexpected losses. However, such a reform advocates an important change in the accounting standards towards an expected loss approach. The Basel Committee has issued a set of high level guiding principles that should govern the reforms to the replacement of IAS 39. 


\section{References}

Ahmed AS, Takeda C, Thomas S. 1999. Bank loan loss provisions: a re-examination of capital management, earnings management and signaling effects. Journal of Accounting and Economics 28: 1-26.

Anandarajan A, Hasan I, McCarthy C. 2007. Use of Loan Loss Provisions for Capital, Earnings Management and Signalling By Australian Banks. Accounting and Finance 47: 357-379.

Accounting and Finance, Vol. 47, No. 3, pp. 357-379, September 2007

Arellano M, Bond SR. 1991. Some tests of specification for panel data: monte carlo evidence and an application to employment equations. Review of Economic Studies 58: 277-297.

Arellano M, Bover O. 1995. Another look at the instrumental variables estimation of errorcomponents models. Journal of Econometrics 68: 29-51.

Basel Committee on Banking Supervision 2011. Basel III: A global regulatory framework for more resilient banks and banking systems. Bank for International Settlement.

Beaver WH, Engel E. 1996. Discretionary behaviour with respect to allowances for loan losses and the behaviour of security prices. Journal of Accounting and Economics 22: 177-206.

Bikker JA, Metzemakers P, 2005. Bank provisioning behaviour and procyclicality. Journal of International Financial Markets, Institutions and Money 15: 141-157.

Blundell R, Bond S. 1998. Initial conditions and moment restrictions in dynamic panel data models. Journal of Econometrics 87: 115-143.

Bouvatier V, Lepetit L. 2012. Provisioning rules and bank lending: A theoretical model. Journal of Financial Stability, forthcoming.

Bouvatier V, Lepetit L. 2011. Canal des provisions bancaires et cycle du marché du crédit. Revue Economique 62: 67-86.

Bouvatier V, Lepetit L. 2008. Banks' procyclical behaviour: Does provisioning matter? Journal of International Financial Markets, Institutions $\&$ Money 18: 513-526.

Cavallo M, Majnoni G. 2001. Do banks provision for bad loans in good time? Empirical evidence and policy implications. World Bank, Working Paper no.2619.

Clerc L, Drumetz F, Jaudoin O. 2001. To what extent are prudential and accounting arrangements pro- or countercyclical with respect to overall financial conditions? BIS Papers no.1, $197-210$.

Fernandez de Lis S, Martinez Pagès J, Saurina J. 2001. Credit growth, problem loans and credit risk provisioning in Spain. BIS Papers no.1, 331-353.

Fonseca AR, Gonzales F. 2008. Cross country determinants of bank income smoothing by managing loan loss provisions. Journal of Banking and Finance 32: 217-228. 
Jiménez G, Saurina J. 2005. Credit cycles, credit risk, and prudential regulation. Bank of Spain, Working Paper no.0531.

Hasan I, Wall L. 2004. Determinants of the loan loss allowance: some cross-country comparison. The Financial Review 39: 129-152.

Kanagaretnam K, Lobo G, Yang D. 2004. Join test of signaling and income smoothing by managing loan loss provisions. Contemporary Accounting Rsearch 21: 843-884.

Kanagaretnam K, Krishan G, Lobo G. 2009. Is the market valuation of banks' loan loss provision conditional on auditor reputation? Journal of Banking and Finance 33: 10391047.

Laeven L, Majnoni G. 2003. Loan loss provisioning and economic slowdowns: too much, too late? Journal of Financial Intermediation 12: 178-197.

Liu CC, Ryan SG, Wahlen JM. 1997. Differential valuation implications of loan loss provisions across banks and fiscal quarters. The Accounting Review 72: 133-146.

Lobo GJ, Yang DH. 2001. Bank managers' heterogeneous decisions on discretionary loan loss provisions. Review of Quantitative Finance and Accounting 16: 223-250.

Pain D. 2003. The provisioning experience of the major UK banks: a small panel investigation. Bank of England, Working Paper no.177.

Roodman D. 2006. How to Do xtabond2: An Introduction to "Difference" and "System" GMM in Stata. Center for Global Development, Working Papers 103

Saurina J. 2009. Dynamic Provisioning, The Experience of Spain. The World Bank Group, Financial and Private Sector Development Vice-presidency. Number 7.

Shrieves RE, Dahl D. 2002. Discretionary accounting and the behaviour of Japanese banks under financial distress. Journal of banking and finance 27: 1219-1243.

Windmeijer F. 2005. A finite sample correction for the variance of linear efficient two-step GMM estimators. Journal of Econometrics 126: 25-51.

Whalen JM. 1994. The nature of information in commercial bank loan loss disclosures. The Accounting Review 69: 455-478. 
Table 1: General descriptive statistics on average over the period of analysis

\begin{tabular}{|c|c|c|c|c|c|c|}
\hline & $\begin{array}{c}\text { European banks } \\
\text { (whole sample) } \\
1995-2008 \\
\end{array}$ & $\begin{array}{c}\text { European banks } \\
\text { (without Italy) } \\
1995-2008 \\
\end{array}$ & $\begin{array}{c}\text { Japanese } \\
\text { banks } \\
1998-2008 \\
\end{array}$ & $\begin{array}{c}\text { US banks } \\
1995-2008 \\
\end{array}$ & $\begin{array}{c}\text { Central \& South } \\
\text { American banks } \\
1995-2008 \\
\end{array}$ & $\begin{array}{c}\text { South \& East } \\
\text { Asian banks } \\
1998-2008 \\
\end{array}$ \\
\hline$L$ & $\begin{array}{c}62.21 \\
(20.55)\end{array}$ & $\begin{array}{c}66.79 \\
(24.53)\end{array}$ & $\begin{array}{c}56.55 \\
(11.45)\end{array}$ & $\begin{array}{c}64.99 \\
(14.70)\end{array}$ & $\begin{array}{c}51.96 \\
(19.84)\end{array}$ & $\begin{array}{c}57.44 \\
(16.52)\end{array}$ \\
\hline$D$ & $\begin{array}{c}64.41 \\
(15.18)\end{array}$ & $\begin{array}{c}73.95 \\
(15.04)\end{array}$ & $\begin{array}{l}92.16 \\
(6.67)\end{array}$ & $\begin{array}{l}81.49 \\
(9.56)\end{array}$ & $\begin{array}{c}64.92 \\
(22.85)\end{array}$ & $\begin{array}{c}76.79 \\
(14.38)\end{array}$ \\
\hline$N P L$ & $\begin{array}{c}3.67 \\
(3.56)\end{array}$ & $\begin{array}{c}2.45 \\
(3.26)\end{array}$ & $\begin{array}{c}5.28 \\
(3.14)\end{array}$ & $\begin{array}{c}0.66 \\
(1.12)\end{array}$ & $\begin{array}{c}4.36 \\
(5.59)\end{array}$ & $\begin{array}{c}4.43 \\
(5.41)\end{array}$ \\
\hline$L L P$ & $\begin{array}{c}0.33 \\
(0.48)\end{array}$ & $\begin{array}{c}0.26 \\
(0.58)\end{array}$ & $\begin{array}{c}0.43 \\
(0.51)\end{array}$ & $\begin{array}{c}0.28 \\
(0.59)\end{array}$ & $\begin{array}{c}1.64 \\
(2.63)\end{array}$ & $\begin{array}{c}0.76 \\
(1.02)\end{array}$ \\
\hline$E$ & $\begin{array}{c}9.80 \\
(5.33)\end{array}$ & $\begin{array}{c}7.98 \\
(6.01)\end{array}$ & $\begin{array}{c}5.18 \\
(2.02)\end{array}$ & $\begin{array}{l}10.37 \\
(3.72)\end{array}$ & $\begin{array}{c}15.88 \\
(13.84)\end{array}$ & $\begin{array}{l}10.91 \\
(8.63)\end{array}$ \\
\hline$T C R$ & $\begin{array}{l}16.96 \\
(8.25)\end{array}$ & $\begin{array}{l}15.07 \\
(5.67)\end{array}$ & & $\begin{array}{l}16.28 \\
(7.27)\end{array}$ & & $\begin{array}{c}16.99 \\
(12.51)\end{array}$ \\
\hline$R O A$ & $\begin{array}{c}0.64 \\
(0.79)\end{array}$ & $\begin{array}{c}0.60 \\
(0.97)\end{array}$ & $\begin{array}{l}-0.02 \\
(0.63)\end{array}$ & $\begin{array}{c}0.93 \\
(0.98)\end{array}$ & $\begin{array}{c}1.28 \\
(4.14)\end{array}$ & $\begin{array}{c}0.77 \\
(1.59)\end{array}$ \\
\hline$R O E$ & $\begin{array}{c}7.08 \\
(7.80)\end{array}$ & $\begin{array}{c}7.98 \\
(9.87)\end{array}$ & $\begin{array}{c}-1.46 \\
(14.83)\end{array}$ & $\begin{array}{c}9.53 \\
(9.04)\end{array}$ & $\begin{array}{c}10.80 \\
(18.29)\end{array}$ & $\begin{array}{c}6.71 \\
(15.82)\end{array}$ \\
\hline$E R$ & $\begin{array}{l}1.28 \\
(094)\end{array}$ & $\begin{array}{c}1.12 \\
(1.21)\end{array}$ & $\begin{array}{c}0.49 \\
(0.47)\end{array}$ & $\begin{array}{c}1.51 \\
(1.21)\end{array}$ & $\begin{array}{c}3.32 \\
(4.69)\end{array}$ & $\begin{array}{c}1.79 \\
(1.62)\end{array}$ \\
\hline$\dot{L}$ & $\begin{array}{c}11.32 \\
(15.26)\end{array}$ & $\begin{array}{c}7.96 \\
(16.44)\end{array}$ & $\begin{array}{c}2.29 \\
(11.92)\end{array}$ & $\begin{array}{c}9.51 \\
(15.54)\end{array}$ & $\begin{array}{c}9.38 \\
(32.47)\end{array}$ & $\begin{array}{c}11.71 \\
(18.79)\end{array}$ \\
\hline$\dot{D}$ & $\begin{array}{c}7.85 \\
(15.32)\end{array}$ & $\begin{array}{c}6.88 \\
(17.25)\end{array}$ & $\begin{array}{c}4.44 \\
(12.36)\end{array}$ & $\begin{array}{c}8.16 \\
(14.12)\end{array}$ & $\begin{array}{c}9.45 \\
(32.44)\end{array}$ & $\begin{array}{c}11.48 \\
(19.99)\end{array}$ \\
\hline $\begin{array}{l}\text { No. banks } \\
\text { Obs. }\end{array}$ & $\begin{array}{l}1636 \\
7684\end{array}$ & $\begin{array}{c}842 \\
3158\end{array}$ & $\begin{array}{c}689 \\
4623\end{array}$ & $\begin{array}{c}9421 \\
63244\end{array}$ & $\begin{array}{c}632 \\
2885\end{array}$ & $\begin{array}{c}245 \\
1287\end{array}$ \\
\hline
\end{tabular}

Variable definitions (all variables are expressed in percentages): $L=$ net loans/total assets; $D=$ deposits/total assets; $N P L=$ non performing loans/ total assets; $L L P=$ loan loss provisions/total assets; $E=$ total equity investments/total assets; $T C R=$ total capital ratio; $R O A=$ return on assets; $R O E=$ return on equity; $E R=$ earnings before taxes and loan loss provisions/total assets; $\dot{L}=$ growth rate of net loans; $\dot{D}=$ growth rate of total deposits. Standard deviations are in brackets. 
Table 2: The decomposition of loan loss provisions

Endogenous variable : $L L P_{i, t}$

\begin{tabular}{|c|c|c|c|c|c|c|c|c|}
\hline & \multicolumn{3}{|c|}{$\begin{array}{l}\text { European banks } \\
\text { (whole sample) }\end{array}$} & \multicolumn{3}{|c|}{$\begin{array}{c}\text { European banks } \\
\text { (without Italy) }\end{array}$} & \multicolumn{2}{|c|}{$\begin{array}{c}\text { Japanese } \\
\text { banks }\end{array}$} \\
\hline & $(1 . a)$ & $(1 . b)$ & (1.c) & $(1 . a)$ & (1.b) & (1.c) & (1.a) & (1.c) \\
\hline$\overline{L L L P_{i, t-1}}$ & $\begin{array}{l}0.1900^{\mathrm{a}} \\
(0.0607)\end{array}$ & $\begin{array}{l}0.2519^{\mathrm{a}} \\
(0.0419)\end{array}$ & $\begin{array}{l}0.1722^{\mathrm{a}} \\
(0.0490)\end{array}$ & $\begin{array}{l}0.1858^{\mathrm{b}} \\
(0.0844)\end{array}$ & $\begin{array}{l}0.2540^{\mathrm{a}} \\
(0.0767)\end{array}$ & $\begin{array}{l}0.1682^{\mathrm{b}} \\
(0.0679)\end{array}$ & $\begin{array}{l}-0.0182 \\
(0.0310)\end{array}$ & $\begin{array}{l}-0.0209 \\
(0.0366)\end{array}$ \\
\hline$N P L_{i, t}$ & $\begin{array}{l}0.0391^{\mathrm{a}} \\
(0.0059)\end{array}$ & $\begin{array}{l}0.0361^{\mathrm{a}} \\
(0.0042)\end{array}$ & $\begin{array}{l}0.0391^{\mathrm{a}} \\
(0.0055)\end{array}$ & $\begin{array}{l}0.0485^{\mathrm{a}} \\
(0.0148)\end{array}$ & $\begin{array}{l}0.0941^{\mathrm{a}} \\
(0.0156)\end{array}$ & $\begin{array}{l}0.0468^{\mathrm{a}} \\
(0.0136)\end{array}$ & $\begin{array}{l}0.0837^{\mathrm{a}} \\
(0.0060)\end{array}$ & $\begin{array}{l}0.0725^{\mathrm{a}} \\
(0.0061)\end{array}$ \\
\hline$\Delta N P L_{i, t}$ & $\begin{array}{l}0.0388^{a} \\
(0.0098)\end{array}$ & $\begin{array}{l}0.0312^{\mathrm{a}} \\
(0.0090)\end{array}$ & $\begin{array}{l}0.0358^{a} \\
(0.0086)\end{array}$ & $\begin{array}{l}0.0801^{\mathrm{a}} \\
(0.0242)\end{array}$ & $\begin{array}{l}0.0881^{\mathrm{a}} \\
(0.0292)\end{array}$ & $\begin{array}{l}0.0774^{\mathrm{a}} \\
(0.0275)\end{array}$ & $\begin{array}{l}0.0770^{\mathrm{a}} \\
(0.0103)\end{array}$ & $\begin{array}{l}0.0755^{\mathrm{a}} \\
(0.0080)\end{array}$ \\
\hline$L_{i, t}$ & $\begin{array}{l}0.0033^{\mathrm{a}} \\
(0.0004)\end{array}$ & $\begin{array}{c}0.0005 \\
(0.0005)\end{array}$ & $\begin{array}{l}0.0024^{\mathrm{a}} \\
(0.0004)\end{array}$ & $\begin{array}{l}0.0033^{\mathrm{a}} \\
(0.0008)\end{array}$ & $\begin{array}{c}0.0005 \\
(0.0011)\end{array}$ & $\begin{array}{l}0.0025^{\mathrm{a}} \\
(0.0008)\end{array}$ & $\begin{array}{c}0.0009 \\
(0.0009)\end{array}$ & $\begin{array}{r}-0.0028^{\mathrm{a}} \\
(0.0009)\end{array}$ \\
\hline$\dot{y}_{i, t}$ & $\begin{array}{c}-0.0504^{\mathrm{a}} \\
(0.0108)\end{array}$ & $\begin{array}{c}-0.0463^{\mathrm{a}} \\
(0.0096)\end{array}$ & $\begin{array}{r}-0.0508^{a} \\
(0.0104)\end{array}$ & $\begin{array}{c}-0.0569^{a} \\
(0.0138)\end{array}$ & $\begin{array}{c}-0.0290^{\mathrm{a}} \\
(0.0131)\end{array}$ & $\begin{array}{c}-0.0614^{\mathrm{a}} \\
(0.0144)\end{array}$ & $\begin{array}{c}-0.0210^{\mathrm{a}} \\
(0.005)\end{array}$ & $\begin{array}{c}-0.0201^{\mathrm{a}} \\
(0.0059)\end{array}$ \\
\hline$E R_{i, t}$ & & $\begin{array}{l}0.0800^{\mathrm{a}} \\
(0.0157)\end{array}$ & $\begin{array}{l}0.0822^{\mathrm{a}} \\
(0.0272)\end{array}$ & & $\begin{array}{l}0.1182^{\mathrm{a}} \\
(0.0248)\end{array}$ & $\begin{array}{l}0.0813^{\mathrm{c}} \\
(0.0437)\end{array}$ & & $\begin{array}{l}0.0804^{\mathrm{a}} \\
(0.0308)\end{array}$ \\
\hline$T C R_{i, t}$ & & $\begin{array}{c}-0.0062^{\mathrm{a}} \\
(0.0013)\end{array}$ & & & $\begin{array}{l}-0.0062 \\
(0.0044)\end{array}$ & & & \\
\hline$E_{i, t}$ & & & $\begin{array}{c}-0.0051^{\mathrm{c}} \\
(0.0028)\end{array}$ & & & $\begin{array}{l}-0.0010 \\
(0.0046)\end{array}$ & & $\begin{array}{r}-0.0437^{\mathrm{a}} \\
(0.0081)\end{array}$ \\
\hline Dummies : & & & & & & & & \\
\hline $\begin{array}{l}\text { Time } \\
\text { Country }\end{array}$ & $\begin{array}{l}\text { Yes } \\
\text { Yes }\end{array}$ & $\begin{array}{l}\text { Yes } \\
\text { Yes }\end{array}$ & $\begin{array}{l}\text { Yes } \\
\text { Yes }\end{array}$ & $\begin{array}{l}\text { Yes } \\
\text { Yes }\end{array}$ & $\begin{array}{l}\text { Yes } \\
\text { Yes }\end{array}$ & $\begin{array}{l}\text { Yes } \\
\text { Yes }\end{array}$ & $\begin{array}{l}\text { No } \\
\text { No }\end{array}$ & $\begin{array}{l}\text { No } \\
\text { No }\end{array}$ \\
\hline Type & Yes & Yes & Yes & Yes & Yes & Yes & Yes & Yes \\
\hline $\mathrm{AR}(2)$ test & 0.840 & 0.343 & 0.947 & 0.511 & 0.682 & 0.646 & 0.937 & 0.715 \\
\hline Hansen test & 0.377 & 0.939 & 0.542 & 0.336 & 0.968 & 0.385 & 0.278 & 0.114 \\
\hline No. banks & 1637 & 1140 & 1636 & 842 & 368 & 842 & 692 & 689 \\
\hline Obs. & 7689 & 5456 & 7684 & 3161 & 1198 & 3158 & 4632 & 4623 \\
\hline
\end{tabular}

Note: $\mathrm{a}, \mathrm{b}$ and $\mathrm{c}$ indicate significance respectively at the $1 \%, 5 \%$ and $10 \%$ levels. Standard deviations are in brackets. Variable definitions : $L L P_{i, t}$ : loan loss provisions/total assets; $N P L_{i, t}$ : non performing loans/total assets; $\triangle N P L_{i, t}=N P L_{i, t}-N P L_{i, t-1} ; L_{i, t}$ : net loans/total assets; $\dot{y}_{i, t}$ : GDP growth rate; $E R_{i, t}$ : earnings before taxes and loan loss provisions/total assets; $T C R_{i, t}$ : total capital ratio; $E_{i, t}$ : total equity investments/total assets. 
Table 3: The decomposition of loan loss provisions

Endogenous variable : $L L P_{i, t}$

\begin{tabular}{|c|c|c|c|c|c|c|c|c|}
\hline & \multicolumn{3}{|c|}{ US banks } & \multicolumn{2}{|c|}{$\begin{array}{l}\text { Central \& South } \\
\text { American banks }\end{array}$} & \multicolumn{3}{|c|}{$\begin{array}{c}\text { South \& East } \\
\text { Asian banks }\end{array}$} \\
\hline & (1.a) & $(\mathbf{1 . b})$ & (1.c) & (1.a) & (1.c) & (1.a) & $(1 . b)$ & (1.c) \\
\hline$\overline{L L P_{i, t-1}}$ & $\begin{array}{l}0.3347^{\mathrm{a}} \\
(0.0351)\end{array}$ & $\begin{array}{l}0.3221^{\mathrm{a}} \\
(0.0328)\end{array}$ & $\begin{array}{l}0.3372^{\mathrm{a}} \\
(0.0268)\end{array}$ & $\begin{array}{l}0.3388^{\mathrm{a}} \\
(0.0632)\end{array}$ & $\begin{array}{l}0.3033^{\mathrm{a}} \\
(0.0618)\end{array}$ & $\begin{array}{l}0.1171^{\mathrm{a}} \\
(0.0416)\end{array}$ & $\begin{array}{c}0.0707 \\
(0.0558)\end{array}$ & $\begin{array}{c}0.0736 \\
(0.0498)\end{array}$ \\
\hline$N P L_{i, t}$ & $\begin{array}{l}0.1606^{\mathrm{a}} \\
(0.0158)\end{array}$ & $\begin{array}{l}0.1647^{\mathrm{a}} \\
(0.0177)\end{array}$ & $\begin{array}{l}0.1659^{\mathrm{a}} \\
(0.0170)\end{array}$ & $\begin{array}{l}0.1155^{\mathrm{a}} \\
(0.0223)\end{array}$ & $\begin{array}{l}0.1205^{\mathrm{a}} \\
(0.0224)\end{array}$ & $\begin{array}{l}0.0788^{\mathrm{a}} \\
(0.0222)\end{array}$ & $\begin{array}{l}0.0984^{\mathrm{a}} \\
(0.0218)\end{array}$ & $\begin{array}{l}0.0722^{\mathrm{a}} \\
(0.0178)\end{array}$ \\
\hline$\triangle N P L_{i, t}$ & $\begin{array}{l}0.0632^{\mathrm{a}} \\
(0.0132)\end{array}$ & $\begin{array}{l}0.0636^{\mathrm{a}} \\
(0.0133)\end{array}$ & $\begin{array}{l}0.0574^{\mathrm{a}} \\
(0.0128)\end{array}$ & $\begin{array}{l}0.1489^{\mathrm{a}} \\
(0.0236)\end{array}$ & $\begin{array}{l}0.1209^{\mathrm{a}} \\
(0.0226)\end{array}$ & $\begin{array}{c}0.0391 \\
(0.0306)\end{array}$ & $\begin{array}{c}0.0303 \\
(0.0328)\end{array}$ & $\begin{array}{c}0.0189 \\
(0.0220)\end{array}$ \\
\hline$L_{i, t}$ & $\begin{array}{l}0.0032^{\mathrm{a}} \\
(0.0002)\end{array}$ & $\begin{array}{l}0.0010^{\mathrm{a}} \\
(0.0002)\end{array}$ & $\begin{array}{l}0.0022^{\mathrm{a}} \\
(0.0002)\end{array}$ & $\begin{array}{l}0.0090^{\mathrm{a}} \\
(0.0029)\end{array}$ & $\begin{array}{l}0.0060^{\mathrm{b}} \\
(0.0024)\end{array}$ & $\begin{array}{r}0.0005 \\
(0.0026)\end{array}$ & $\begin{array}{l}-0.0017 \\
(0.0033)\end{array}$ & $\begin{array}{l}-0.0021 \\
(0.0021)\end{array}$ \\
\hline$\dot{y}_{i, t}$ & $\begin{array}{l}-0.0410^{\mathrm{a}} \\
(0.0022)\end{array}$ & $\begin{array}{l}-0.0428^{a} \\
(0.0022)\end{array}$ & $\begin{array}{c}-0.0437^{\mathrm{a}} \\
(0.0021)\end{array}$ & $\begin{array}{l}-0.0949^{a} \\
(0.0133)\end{array}$ & $\begin{array}{r}-0.0825^{a} \\
(0.0141)\end{array}$ & $\begin{array}{r}-0.0345^{a} \\
(0.0122)\end{array}$ & $\begin{array}{l}-0.0299^{b} \\
(0.0146)\end{array}$ & $\begin{array}{r}-0.0271^{b} \\
(0.0109)\end{array}$ \\
\hline$E R_{i, t}$ & & $\begin{array}{l}0.0686^{\mathrm{a}} \\
(0.0124)\end{array}$ & $\begin{array}{l}0.0663^{\mathrm{a}} \\
(0.0116)\end{array}$ & & $\begin{array}{l}0.1394^{\mathrm{a}} \\
(0.0312)\end{array}$ & & $\begin{array}{l}0.1153^{b} \\
(0.0536)\end{array}$ & $\begin{array}{l}0.1600^{\mathrm{a}} \\
(0.0472)\end{array}$ \\
\hline$T C R_{i, t}$ & & $\begin{array}{r}-0.0054^{\mathrm{a}} \\
(0.0005)\end{array}$ & & & & & $\begin{array}{r}-0.0120^{\mathrm{a}} \\
(0.0037)\end{array}$ & \\
\hline$E_{i, t}$ & & & $\begin{array}{r}-0.0076^{\mathrm{a}} \\
(0.0014)\end{array}$ & & $\begin{array}{l}-0.0033 \\
(0.0047)\end{array}$ & & & $\begin{array}{r}-0.0217^{\mathrm{a}} \\
(0.0079)\end{array}$ \\
\hline $\begin{array}{c}\text { Dummies : } \\
\text { Time }\end{array}$ & $\mathrm{No}_{\mathrm{O}}$ & No & $\mathrm{No}$ & Yes & Yes & Yes & Yes & Yes \\
\hline Country & No & No & No & Yes & Yes & Yes & Yes & Yes \\
\hline Type & Yes & Yes & Yes & Yes & Yes & Yes & Yes & Yes \\
\hline $\mathrm{AR}(2)$ test & 0.124 & 0.130 & 0.121 & 0.663 & 0.712 & 0.085 & 0.144 & 0.059 \\
\hline Hansen test & 0.155 & 0.028 & 0.161 & 0.498 & 0.515 & 0.083 & 0.045 & 0.063 \\
\hline No. banks & 9422 & 9413 & 9421 & 637 & 632 & 246 & 228 & 245 \\
\hline Obs. & 63265 & 63184 & 63244 & 2904 & 2885 & 1294 & 1141 & 1287 \\
\hline
\end{tabular}

Note: $\mathrm{a}, \mathrm{b}$ and $\mathrm{c}$ indicate significance respectively at the $1 \%, 5 \%$ and $10 \%$ levels. Standard deviations are in brackets. Variable definitions : $L L P_{i, t}$ : loan loss provisions/total assets; $N P L_{i, t}$ : non performing loans/total assets; $\triangle N P L_{i, t}=N P L_{i, t}-N P L_{i, t-1} ; L_{i, t}$ : net loans/total assets; $\dot{y}_{i, t}$ : GDP growth rate; $E R_{i, t}$ : earnings before taxes and loan loss provisions/total assets; $T C R_{i, t}$ : total capital ratio; $E_{i, t}$ : total equity investments/total assets. 
Table 4: Backward looking provisioning rules and growth in bank lending

Endogenous variable : $\dot{L}_{i, t}$

\begin{tabular}{|c|c|c|c|c|c|c|c|c|c|c|c|c|}
\hline & \multicolumn{4}{|c|}{$\begin{array}{l}\text { European banks } \\
\text { (whole sample) }\end{array}$} & \multicolumn{4}{|c|}{$\begin{array}{l}\text { European banks } \\
\text { (without Italy) }\end{array}$} & \multicolumn{4}{|c|}{ Japanese banks } \\
\hline & $(2 . a)$ & $(2 . b)$ & (2.c) & (2.d) & (2.a) & $(2 . b)$ & $(2 . c)$ & (2.d) & $(2 . \mathbf{a})$ & $(2 . b)$ & $(2 . c)$ & $(2 . d)$ \\
\hline$N D I S C 1_{i, t}$ & $\begin{array}{c}-15.07^{\mathrm{a}} \\
(5.40)\end{array}$ & & & $\begin{array}{l}-7.08^{\mathrm{b}} \\
(3.12)\end{array}$ & $\begin{array}{l}-13.52^{\mathrm{b}} \\
(5.61)\end{array}$ & & & $\begin{array}{l}-7.65^{\mathrm{b}} \\
(3.46)\end{array}$ & $\begin{array}{l}-1.68 \\
(1.90)\end{array}$ & & & $\begin{array}{l}-1.04 \\
(2.26)\end{array}$ \\
\hline$N D I S C 2_{i, t}$ & & $\begin{array}{r}-15.21^{\mathrm{a}} \\
(5.90)\end{array}$ & & & & $\begin{array}{r}-13.12^{\mathrm{b}} \\
(5.83)\end{array}$ & & & & $\begin{array}{l}-1.58 \\
(1.93)\end{array}$ & & \\
\hline$N D I S C 3_{i, t}$ & & & $\begin{array}{c}-11.23^{\mathrm{b}} \\
(5.19)\end{array}$ & & & & $\begin{array}{c}-14.90^{\mathrm{b}} \\
(6.17)\end{array}$ & & & & $\begin{array}{l}-2.15 \\
(1.93)\end{array}$ & \\
\hline$D I S C_{i, t}$ & & & & $\begin{array}{c}-3.84 \\
(10.09)\end{array}$ & & & & $\begin{array}{l}-4.71 \\
(6.26)\end{array}$ & & & & $\begin{array}{l}-0.32 \\
(2.19)\end{array}$ \\
\hline$\dot{D}_{i, t}$ & $\begin{array}{l}0.94^{\mathrm{a}} \\
(0.15)\end{array}$ & $\begin{array}{l}0.96^{\mathrm{a}} \\
(0.15)\end{array}$ & $\begin{array}{l}0.96^{\mathrm{a}} \\
(0.16)\end{array}$ & $\begin{array}{c}0.92^{\mathrm{a}} \\
(0.16)\end{array}$ & $\begin{array}{l}0.72^{\mathrm{a}} \\
(0.15)\end{array}$ & $\begin{array}{l}0.73^{\mathrm{a}} \\
(0.15)\end{array}$ & $\begin{array}{l}0.65^{\mathrm{a}} \\
(0.14)\end{array}$ & $\begin{array}{l}0.75^{\mathrm{a}} \\
(0.14)\end{array}$ & $\begin{array}{l}0.73^{\mathrm{a}} \\
(0.14)\end{array}$ & $\begin{array}{l}0.71^{\mathrm{a}} \\
(0.14)\end{array}$ & $\begin{array}{l}0.77^{\mathrm{a}} \\
(0.16)\end{array}$ & $\begin{array}{l}0.82^{\mathrm{a}} \\
(0.16)\end{array}$ \\
\hline$E_{i, t-1}$ & $\begin{array}{l}-0.08^{\mathrm{c}} \\
(0.04)\end{array}$ & $\begin{array}{l}-0.09^{\mathrm{c}} \\
(0.05)\end{array}$ & $\begin{array}{l}-0.07 \\
(0.05)\end{array}$ & $\begin{array}{l}-0.05 \\
(0.05)\end{array}$ & $\begin{array}{l}-0.18^{b} \\
(0.07)\end{array}$ & $\begin{array}{l}-0.19^{\mathrm{a}} \\
(0.07)\end{array}$ & $\begin{array}{l}-0.08 \\
(0.07)\end{array}$ & $\begin{array}{l}-0.19^{b} \\
(0.08)\end{array}$ & $\begin{array}{l}-0.11 \\
(0.09)\end{array}$ & $\begin{array}{l}-0.10 \\
(0.09)\end{array}$ & $\begin{array}{l}-0.14 \\
(0.10)\end{array}$ & $\begin{array}{l}-0.12 \\
(0.11)\end{array}$ \\
\hline$T A_{i, t-1}$ & $\begin{array}{l}-0.61^{\mathrm{a}} \\
(0.18)\end{array}$ & $\begin{array}{r}-0.62^{\mathrm{a}} \\
(0.19)\end{array}$ & $\begin{array}{l}-0.42^{\mathrm{a}} \\
(0.16)\end{array}$ & $\begin{array}{l}-0.42^{\mathrm{a}} \\
(0.14)\end{array}$ & $\begin{array}{l}-0.75^{\mathrm{a}} \\
(0.27)\end{array}$ & $\begin{array}{l}-0.74^{\mathrm{a}} \\
(0.27)\end{array}$ & $\begin{array}{l}-0.86^{\mathrm{a}} \\
(0.32)\end{array}$ & $\begin{array}{c}-0.49^{b} \\
(0.20)\end{array}$ & $\begin{array}{l}-0.18 \\
(0.12)\end{array}$ & $\begin{array}{l}-0.17 \\
(0.12)\end{array}$ & $\begin{array}{l}-0.21 \\
(0.13)\end{array}$ & $\begin{array}{l}-0.13 \\
(0.14)\end{array}$ \\
\hline $\begin{array}{c}\text { Dummies } \\
\text { Time }\end{array}$ & Yes & Yes & Yes & Yes & Yes & Yes & Yes & Yes & Yes & Yes & Yes & Yes \\
\hline Country & Yes & Yes & Yes & Yes & Yes & Yes & Yes & Yes & No & No & No & $\mathrm{No}$ \\
\hline Type & Yes & Yes & Yes & Yes & Yes & Yes & Yes & Yes & Yes & Yes & Yes & Yes \\
\hline "AR(2) test & 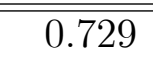 & 0.709 & 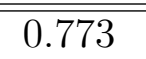 & 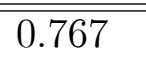 & 0.098 & 0.097 & $\overline{00.113}$ & 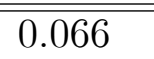 & 0.239 & 0.248 & 0.195 & 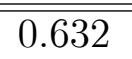 \\
\hline Hansen test & 0.402 & 0.690 & 0.425 & 0.326 & 0.460 & 0.697 & 0.585 & 0.673 & 0.331 & 0.305 & 0.258 & 0.029 \\
\hline No. banks & 1605 & 1605 & 1605 & 1605 & 825 & 825 & 825 & 825 & 687 & 687 & 687 & 687 \\
\hline Obs. & 7273 & 7273 & 7273 & 7273 & 2948 & 2948 & 2948 & 2948 & 4599 & 4599 & 4599 & 4599 \\
\hline
\end{tabular}

Note: a, b and c indicate significance respectively at the $1 \%, 5 \%$ and $10 \%$ levels. Standard deviations are in brackets. Variable definitions : $\dot{L}_{i, t}$ : growth rate of net loans (in percentage); $\dot{D}_{i, t}$ : growth rate of total deposits (in percentage); NDISC1 $1_{i, t}$, $N D I S C 2_{i, t}$ and $N D I S C 3_{i, t}$ : the non discretionary component of LLP; DISC $C_{i, t}$ : the discretionary component of LLP; $E_{i, t}$ : total equity investments/total assets; $T A_{i, t}$ : logarithme of total assets. 
Table 5: Backward looking provisioning rules and growth in bank lending

Endogenous variable : $\dot{L}_{i, t}$

\begin{tabular}{|c|c|c|c|c|c|c|c|c|c|c|c|c|}
\hline & \multicolumn{4}{|c|}{ US banks } & \multicolumn{4}{|c|}{$\begin{array}{l}\text { Central \& South } \\
\text { American banks }\end{array}$} & \multicolumn{4}{|c|}{$\begin{array}{c}\text { South \& East } \\
\text { Asian banks }\end{array}$} \\
\hline$N D I S C 1_{i, t}$ & $\begin{array}{c}-3.83^{\mathrm{a}} \\
(0.57)\end{array}$ & & & $\begin{array}{l}-3.65^{\mathrm{a}} \\
(0.63)\end{array}$ & $\begin{array}{c}-3.84^{\mathrm{b}} \\
(1.55)\end{array}$ & & & $\begin{array}{c}-3.28^{\mathrm{b}} \\
(1.32)\end{array}$ & $\begin{array}{c}-15.05^{\mathrm{a}} \\
(3.08)\end{array}$ & & & $\begin{array}{r}-15.98^{\mathrm{a}} \\
(4.75)\end{array}$ \\
\hline$N D I S C 2_{i, t}$ & & $\begin{array}{l}-3.80^{\mathrm{a}} \\
(0.57)\end{array}$ & & & & $\begin{array}{c}-2.75^{\mathrm{b}} \\
(1.39)\end{array}$ & & & & $\begin{array}{c}-15.00^{\mathrm{a}} \\
(3.37)\end{array}$ & & \\
\hline$N D I S C 3_{i, t}$ & & & $\begin{array}{l}-3.80^{\mathrm{a}} \\
(0.56)\end{array}$ & & & & $\begin{array}{l}-2.50^{\mathrm{c}} \\
(1.42)\end{array}$ & & & & $\begin{array}{c}-11.08^{\mathrm{a}} \\
(2.89)\end{array}$ & \\
\hline$D I S C_{i, t}$ & & & & $\begin{array}{l}-3.80 \\
(3.84)\end{array}$ & & & & $\begin{array}{l}-0.38 \\
(1.92)\end{array}$ & & & & $\begin{array}{c}3.24 \\
(4.48)\end{array}$ \\
\hline$\dot{D}_{i, t}$ & $\begin{array}{l}1.11^{\mathrm{a}} \\
(0.04)\end{array}$ & $\begin{array}{l}1.11^{\mathrm{a}} \\
(0.04)\end{array}$ & $\begin{array}{l}1.11^{\mathrm{a}} \\
(0.04)\end{array}$ & $\begin{array}{l}1.08^{\mathrm{a}} \\
(0.05)\end{array}$ & $\begin{array}{c}0.95^{\mathrm{a}} \\
(0.16)\end{array}$ & $\begin{array}{c}0.97^{\mathrm{a}} \\
(0.15)\end{array}$ & $\begin{array}{l}1.01^{\mathrm{a}} \\
(0.17)\end{array}$ & $\begin{array}{c}0.97^{\mathrm{a}} \\
(0.17)\end{array}$ & $\begin{array}{l}0.36^{\mathrm{b}} \\
(0.17)\end{array}$ & $\begin{array}{c}0.30^{\mathrm{c}} \\
(0.16)\end{array}$ & $\begin{array}{c}0.32^{\mathrm{c}} \\
(0.17)\end{array}$ & $\begin{array}{c}0.65^{\mathrm{a}} \\
(0.22)\end{array}$ \\
\hline$E_{i, t-1}$ & $\begin{array}{l}-0.26^{\mathrm{a}} \\
(0.05)\end{array}$ & $\begin{array}{l}-0.26^{\mathrm{a}} \\
(0.05)\end{array}$ & $\begin{array}{l}-0.25^{\mathrm{a}} \\
(0.05)\end{array}$ & $\begin{array}{l}-0.23^{\mathrm{a}} \\
(0.06)\end{array}$ & $\begin{array}{l}-0.20^{\mathrm{a}} \\
(0.05)\end{array}$ & $\begin{array}{l}-0.19^{\mathrm{a}} \\
(0.05)\end{array}$ & $\begin{array}{l}-0.18^{\mathrm{a}} \\
(0.06)\end{array}$ & $\begin{array}{l}-0.19^{\mathrm{a}} \\
(0.06)\end{array}$ & $\begin{array}{l}-0.08 \\
(0.06)\end{array}$ & $\begin{array}{l}-0.07 \\
(0.05)\end{array}$ & $\begin{array}{l}-0.02 \\
(0.06)\end{array}$ & $\begin{array}{l}-0.11 \\
(0.13)\end{array}$ \\
\hline$T A_{i, t-1}$ & $\begin{array}{l}-0.07 \\
(0.07)\end{array}$ & $\begin{array}{l}-0.07 \\
(0.07)\end{array}$ & $\begin{array}{l}-0.12 \\
(0.07)\end{array}$ & $\begin{array}{l}-0.20 \\
(0.14)\end{array}$ & $\begin{array}{l}-0.31 \\
(0.44)\end{array}$ & $\begin{array}{l}-0.17 \\
(0.42)\end{array}$ & $\begin{array}{l}-0.16 \\
(0.45)\end{array}$ & $\begin{array}{l}-0.26 \\
(0.47)\end{array}$ & $\begin{array}{l}-1.06^{\mathrm{b}} \\
(0.47)\end{array}$ & $\begin{array}{l}-1.06^{\mathrm{b}} \\
(0.46)\end{array}$ & $\begin{array}{l}-0.77 \\
(0.48)\end{array}$ & $\begin{array}{l}-0.52 \\
(0.64)\end{array}$ \\
\hline $\begin{array}{c}\text { Dummies : } \\
\text { Time } \\
\text { Country } \\
\text { Type }\end{array}$ & $\begin{array}{l}\text { Yes } \\
\text { No } \\
\text { Yes }\end{array}$ & $\begin{array}{l}\text { Yes } \\
\text { No } \\
\text { Yes }\end{array}$ & $\begin{array}{l}\text { Yes } \\
\text { No } \\
\text { Yes }\end{array}$ & $\begin{array}{l}\text { Yes } \\
\text { No } \\
\text { Yes }\end{array}$ & $\begin{array}{l}\text { Yes } \\
\text { Yes } \\
\text { Yes }\end{array}$ & $\begin{array}{l}\text { Yes } \\
\text { Yes } \\
\text { Yes }\end{array}$ & $\begin{array}{l}\text { Yes } \\
\text { Yes } \\
\text { Yes }\end{array}$ & $\begin{array}{l}\text { Yes } \\
\text { Yes } \\
\text { Yes }\end{array}$ & $\begin{array}{l}\text { Yes } \\
\text { Yes } \\
\text { Yes }\end{array}$ & $\begin{array}{l}\text { Yes } \\
\text { Yes } \\
\text { Yes }\end{array}$ & $\begin{array}{l}\text { Yes } \\
\text { Yes } \\
\text { Yes }\end{array}$ & $\begin{array}{l}\text { Yes } \\
\text { Yes } \\
\text { Yes }\end{array}$ \\
\hline $\begin{array}{c}\mathrm{AR}(2) \text { test } \\
\text { Hansen test } \\
\text { No. banks } \\
\text { Obs. }\end{array}$ & $\begin{array}{c}0.421 \\
0.154 \\
9323 \\
62152\end{array}$ & $\begin{array}{r}0.418 \\
0.147 \\
9323 \\
62152\end{array}$ & $\begin{array}{l}0.444 \\
0.121 \\
9323 \\
62152\end{array}$ & $\begin{array}{l}0.214 \\
0.020 \\
9323 \\
62152\end{array}$ & $\begin{array}{r}0.728 \\
0.137 \\
614 \\
2614\end{array}$ & $\begin{array}{cc} & 0.697 \\
& 0.744 \\
4 & 614 \\
4 & 2614\end{array}$ & $\begin{array}{l}0.791 \\
0.220 \\
614 \\
2614\end{array}$ & $\begin{array}{l}0.713 \\
0.236 \\
614 \\
2614\end{array}$ & $\begin{array}{c}0.872 \\
0.360 \\
231 \\
1121\end{array}$ & $\begin{array}{c}0.768 \\
0.699 \\
231 \\
1121\end{array}$ & $\begin{array}{c}0.977 \\
0.336 \\
231 \\
1121\end{array}$ & $\begin{array}{c}0.602 \\
0.015 \\
231 \\
1121\end{array}$ \\
\hline
\end{tabular}

Note: a, b and c indicate significance respectively at the 1\%, 5\% and $10 \%$ levels. Standard deviations are in brackets. Variable definitions : $\dot{L}_{i, t}$ : growth rate of net loans (in percentage); $\dot{D}_{i, t}$ : growth rate of total deposits (in percentage); NDISC1 $1_{i, t}$, $N D I S C 2_{i, t}$ and $N D I S C 3_{i, t}$ : the non discretionary component of LLP; DISC $C_{i, t}$ : the discretionary component of LLP; $E_{i, t}$ : total equity investments/total assets; $T A_{i, t}$ : logarithme of total assets. 
Figure 1: Effect of an increase in non discretionary component of LLP on growth in bank lending

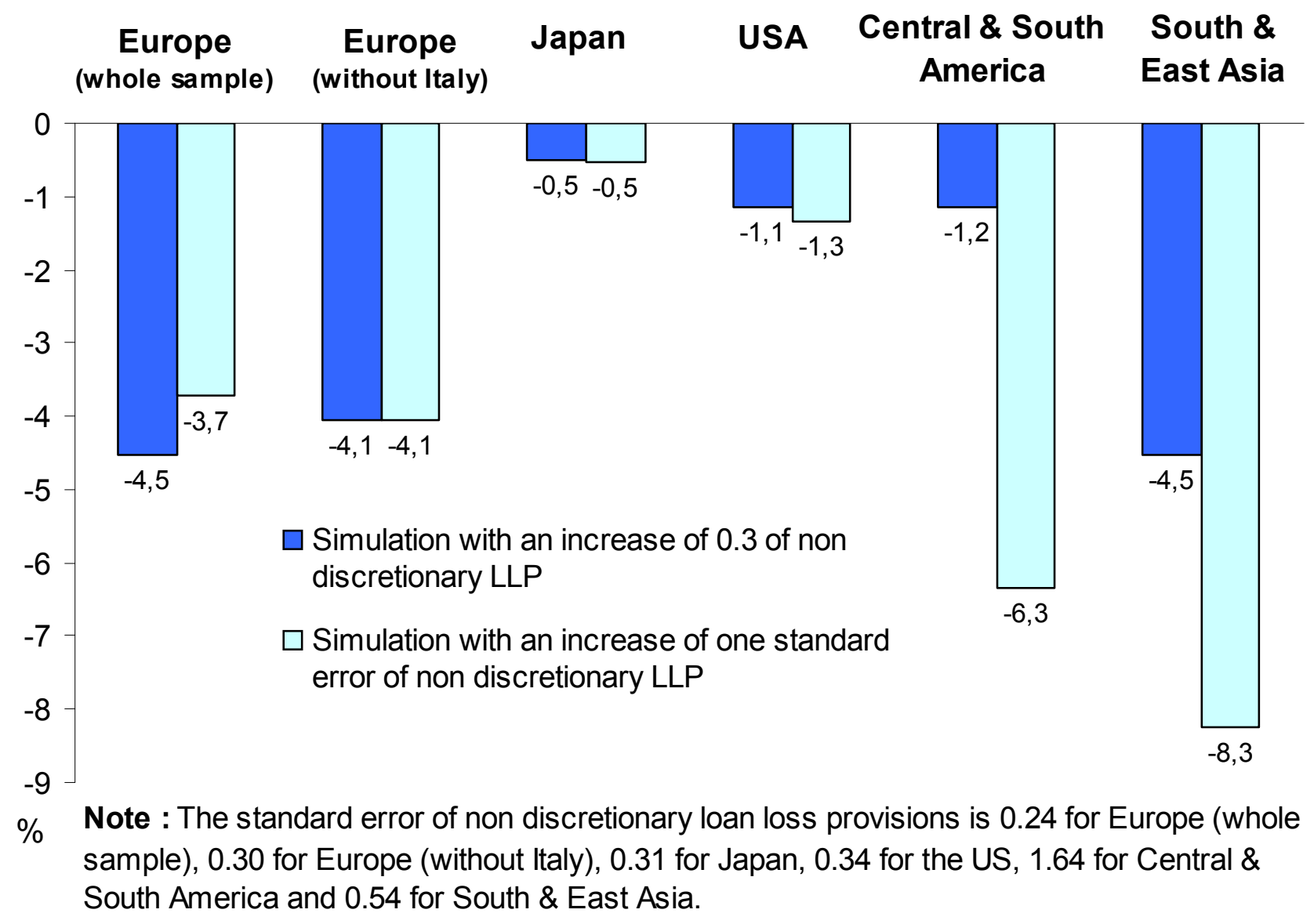




\section{Appendix:}

Table A1. Distribution of banks by country and type

\begin{tabular}{lcccc}
\hline \hline Country & $\begin{array}{c}\text { Total number } \\
\text { of banks }\end{array}$ & $\begin{array}{c}\text { Commercial } \\
\text { banks }\end{array}$ & $\begin{array}{c}\text { Savings } \\
\text { banks }\end{array}$ & $\begin{array}{c}\text { Mutual \& } \\
\text { cooperative banks }\end{array}$ \\
\hline \hline Europe & $\mathbf{1 6 3 6}$ & $\mathbf{5 4 6}$ & $\mathbf{4 6 9}$ & $\mathbf{6 2 1}$ \\
- Denmark & 70 & 49 & 20 & 1 \\
- France & 266 & 164 & 29 & 73 \\
- Italy & 794 & 186 & 75 & 533 \\
- Norway & 130 & 20 & 110 & 0 \\
- Spain & 46 & 10 & 28 & 8 \\
- Sweden & 62 & 19 & 43 & 0 \\
- Switzerland & 237 & 67 & 162 & 8 \\
- U.K. & 31 & 31 & 0 & 0 \\
United States & $\mathbf{9 4 2 1}$ & $\mathbf{8 4 4 7}$ & $\mathbf{9 7 4}$ & $\mathbf{0}$ \\
Central \& South America & $\mathbf{6 3 2}$ & $\mathbf{5 8 1}$ & $\mathbf{1 1}$ & $\mathbf{4 0}$ \\
- Argentina & 80 & 73 & 2 & 5 \\
- Bolivia & 17 & 17 & 0 & 0 \\
- Brazil & 170 & 168 & 0 & 2 \\
- Chile & 44 & 44 & 0 & 0 \\
- Colombia & 47 & 45 & 0 & 2 \\
- Costa Rica & 44 & 17 & 1 & 26 \\
- Ecuador & 38 & 37 & 1 & 0 \\
- Mexico & 41 & 41 & 0 & 0 \\
- Paraguay & 23 & 23 & 0 & 0 \\
- Peru & 30 & 30 & 0 & 0 \\
- Uruguay & 36 & 31 & 0 & 5 \\
- Venezuela & 62 & 55 & 7 & 0 \\
Japan & $\mathbf{6 8 9}$ & $\mathbf{1 4 9}$ & $\mathbf{0}$ & $\mathbf{5 4 0}$ \\
South \& East Asia & $\mathbf{2 4 5}$ & $\mathbf{2 3 2}$ & $\mathbf{1 1}$ & $\mathbf{2}$ \\
- Indonesia & 53 & 53 & 0 & 0 \\
- South Korea & 17 & 17 & 0 & 0 \\
- Malaysia & 43 & 42 & 0 & 1 \\
- Philippines & 47 & 37 & 10 & 0 \\
- Taiwan & 63 & 62 & 0 & 1 \\
- Thailand & 22 & 21 & 1 & 0 \\
\hline \hline & & & & \\
\hline
\end{tabular}

